\title{
PEMODELAN INCIDENT RATE DEMAM BERDARAH DENGUE DI INDONESIA YANG BERKAITAN DENGAN FAKTOR LINGKUNGAN MENGGUNAKAN METODE GEOGRAPHICALLY WEIGHTED REGRESSION (GWR)
}

\author{
Kiki Amelia ${ }^{1}$, Latifa Oktafiani Asril ${ }^{1}$, Lasmi Febrianti ${ }^{1}$ \\ ${ }^{1}$ Program Pendidikan S-1 Statistika, FMIPA Universitas Padjadjaran \\ e-mail: kiki18003@mail.unpad.ac.id
}

diterima: 5 Agustus 2020; direvisi:19 Oktober 2020; disetujui: 22 Oktober 2020

\begin{abstract}
ABSTRAK
Kasus demam berdarah dengue (DBD) di Indonesia sering terjadi di kota dan desa. Setiap tahunnya ratusan hingga ribuan orang harus dirawat di rumah sakit akibat penyakit ini. Ada beberapa faktor dari lingkungan fisik secara langsung maupun tidak langsung sangat berpengaruh pada penularan penyakit ini. Seperti curah hujan, suhu udara, dan kelembaban udara. Selain lingkungan fisik ada beberapa faktor lain yang bisa meningkatkan terjadinya kasus demam berdarah, yaitu kepadatan penduduk dan tingkat angka bebas jentik di suatu daerah. Untuk itu dilakukan suatu penelitian terhadap faktor di atas serta kontribusinya dalam penambahan kasus demam berdarah yang terjadi di Indonesia tahun 2015 dengan menggunakan data sekunder. Tujuan dari penelitian ini yaitu untuk mengidentifikasi dan membuat pemodelan iricident rate DBD berkaitan dengan faktor lingkungan seperti suhu, kelembaban udara, kepadatan penduduk, dan jumlah curah hujan terhadap angka terjadi kasus demam berdarah dengue di Indonesia tahun 2015. Metode yang digunakan yaitu metode Geographically Weighted Regression (GWR). Dalam model GWR estimasi parameter menggunakan Weighted Least Square (WLS) dengan pembobotan fungsi kernel gaussian. Hasil penelitian menyimpulkan bahwa pemodelan dengan GWR lebih baik dibanding dengan regresi linear dan variabel yang signifikans di tiap daerah berbeda-beda.
\end{abstract}

Kata Kunci: Demam Berdarah Dengue, Geographically Weighted Regression (GWR), Lingkungan Fisik

\section{MODELING OF DENGUE FEVER INCIDENT RATE IN INDONESIA RELATED TO ENVIRONMENTAL FACTORS USING THE GEOGRAPHICALLY WEIGHTED REGRESSION (GWR) METHOD}

\begin{abstract}
Dengue hemorrhagic fever cases in Indonesia often occur in cities and villages. Every year hundreds to thousands of people must be hospitalized due to this disease. There are several factors of the physical environment that directly or indirectly influence the transmission of this disease. Such as rainfall, air temperature, and humidity. In addition to the physical environment there are several other factors that can increase the occurrence of dengue cases, namely population density and the level of larvae free in an area. For this reason, we conducted a study of the above factors and their contribution in the addition of dengue cases that occurred in Indonesia in 2015 using secondary data. The purpose of this study is to identify and make a BDB iricident rate model related to environmental factors such as temperature, humidity, population density, and the amount of rainfall on the number of cases of dengue hemorrhagic fever in Indonesia in 2015. The method used is the Geographically Weighted Regression method. (GWR). In the GWR model the parameter estimation uses Weighted Least Square (WLS) by weighting the gaussian kernel function. The results of the study concluded that modeling with GWR was better than linear regression and the variables were significantly different in each region.
\end{abstract}

Key words: Dengue Fever, Geographically Weighted Regression (GWR), Physical Environment 


\section{PENDAHULUAN}

Demam berdarah dengue (DBD) atau biasa juga dikenal sebagai dengue fever disebabkan oleh nyamuk Aedes Aegypti yang berkembang di daerah tropis dan subtropis, merupakan salah satu penyakit menular yang dapat menimbulkan wabah. Penyakit ini merupakan salah satu masalah kesehatan di Indonesia yang dapat menimbulkan kekawatiran karena perjalanan penyakitnya yang cepat dan dapat menyebabkan kematian dalam waktu singkat.

Menurut WHO, Demam berdarah dengue (DBD) adalah penyakit demam akut yang disebabkan oleh virus dengue yang masuk ke perederan darah manusia melalui gigitan nyamuk Aedes Aegepty dan juga oleh Aedes Albopictus yang biasanya hidup dikebun-kebun.

Virus dengue ini hidup dan berkembang di dalam darah tubuh seseorang selama $4-7$ hari dan akan menjadi sumber penularan DBD. Apabila penderita DBD digigit nyamuk penular, maka virus dalam darah penular akan ikut terisap masuk kedalam lambung nyamuk, kemudian virus ini akan memperbanyak diri dan tersebar diberbagai jaringan tubuh nyamuk, termasuk didalam kelenjar liurnya. Kira-kira dalam 1 minggu setelah darah diisap dari tubuh penderita, nyamuk tersebut akan siap menularkan kepada orang lain. Virus ini akan berada dalam tubuh nyamuk sepanjang hidupnya dan menjadi penular (infektif). Penderita yang terinfeksi gejalanya berupa demam tinggi, disertai dengan sakit kepala, nyeri pada mata, otot dan persendian hingga pendarahan spontan.

Terhitung sejak tahun 1968 World Health Organization (WHO) menetapkan negara Indonesia sebagai negara dengan kasus DBD tertinggi di Asia Tenggara. Kasus ini tersebar di 33 provinsi di indonesia di 357 dari total 480 kabupaten. Dimana pada tahun 2014 kasus tertinggi adalah di Bali $(204,22$ per 100.000 penduduk), Kalimantan Timur (135,46 per 100.000 penduduk) dan Kalimantan Utara
(128,51 per 100.000 penduduk). (Lahdji \& Putra, 2017)

Salah satu pengendalian DBD di Indonesia yang dapat dilakukan adalah kegiatan pemberantasan sarang nyamuk (PSN). Pemerintah mencanangkan pembudidayaan PSN secara berkelanjutan dengan pesan inti $3 \mathrm{M}$ plus dan mewujudkan terlaksananya mewujudkan terlaksananya gerakan 1 rumah I juru pemantau jentik (Jumantik). Pengukuran keberhasilan PSN dengan angka bebas jentik (ABJ). Apabila ABJ > 95\% diharapkan dapat mencegah atau mengurangi kasus penularan DBD (Kosnayani \& Hidayat, 2018).

Lingkungan fisik merupakan segala sesuatu yang berada di sekitar makhluk hidup dan berupa benda mati. Lingkungan fisik merupakan lingkungan penunjang sebagai pelengkap lingkungan biologis. Unsur-unsur dalam lingkungan fisik diantaranta, air, udara, cahaya matahari, tanah, topografi, dan iklim. Keberadaan lingkungan fisik berperan penting dalam terjadinya kasus demam berdarah. Ada beberapa faktor dari lingkungan fisik secara langsung maupun tidak langsung sangat berpengaruh pada penularan penyakit ini. Seperti curah hujan, iklim, suhu udara, kelembaban udara, dan kecepatan angin. Selain lingkungan fisik ada beberapa faktor lain yang bisa meningkatkan terjadinya kasus demam berdarah, yaitu kepadatan penduduk dan tingkat angka bebas jentik di suatu daerah.

Curah hujan merupakan jumlah air hujan yang jatuh selama periode waktu tertentu yang pengukurannya menggunakan satuan tinggi di atas permukaan tanah horizontal yang diasumsikan tidak terjadi infiltrasi, run off, maupun evaporasi. Hujan juga dapat diartikan sebagai ketinggian air hujan yang terkumpul dalam tempat yang datar, tidak menguap, tidak meresap dan tidak mengalir (Suroso 2006). Hujan terjadi karena lapisan atmosfer yang tebal dan suhu yang memenuhi diatas titik leleh es yang berada pada di atas permukaan bumi yang dipengaruhi oleh penambahan uap air ke udara. Genangan yang disebabkan oleh 
hujan menjadi tempat perkembangbiakan nyamuk Aedes Aegepty. Hal yang memicu perkembangan nyamuk Aedes Aegepty ini selain dikarenakan curah hujan meningkat namun ketika suhu meningkat maka jumlah kasus DBD pun akan meningkat. Maka musin penghujan ini merupakan musim meningkatnya kasus DBD.

Iklim didefinisikan sebagai cuaca rata-rata selama periode yang panjang. Perubahan iklim mempengaruhi pola penyakit infeksi karena agen penyakit seperti virus, bakteri dan parasit lainnya serta vektor seperti serangga atau rodensia bersifat sensitif sangat tinggi terhadap suhu, kelembaban dan kondisi lingkungan ambien lainnya. Indonesia adalah negara yang berada di garis khatulistiwa. Akibatnya Indonesia memiliki iklim tropis dimana terdapat musim kemarau dan musim penghujan. Dua musim ini sangat berpengaruh terhadap kelangsungan hidup makhluk hidup di wilayah Indonesia termasuk perkembangan nyamuk Aegypti saat musim penghujan tiba.

Kelembaban udara adalah jumlah keselurahan uap air yang berada dalam udara. Pengertian lain dari kelembaban itu sendiri adalah perbandingan antara jumlah uap air yang ada dalam udara pada suatu waktu tertentu dengan jumlah uap air maksimal pada udara pada tekanan dan temperatur suhu yang sama. Terdapat dua macam kelembapan udara yaitu kelembapan udara absolut dan kelembapan udara relatif. Kelembapan udara absolut, adalah banyaknya uap air yang terdapat di udara pada suatu tempat. Kemudian kelembapan udara relatif ialah perbandingan jumlah uap air dalam udara dengan jumlah uap air maksimum yang dapat dikandung oleh udara tersebut dalam suhu yang sama dan dinyatakan dalam persen. Terdapat uap air di udara yang berasal dari penguapan samudra sebagai sumber yang utama. Karena semakin tinggi suhu udara, makin banyak uap air yang dapat dikandungnya. Hal ini berarti udara menjadi lebih lembap. Alat untuk mengukur kelembapan udara dinamakan higrometer (Regariana, 2004).
Kelembaban udara mempengaruhi keberlangsungan hidup nyamuk. Kelembaban yang rendah memperpendek usia nyamuk sedangkan kelembaban tinggi memperpanjang usia nyamuk. Batas paling rendah kelembaban udara adalah $60 \%$, kurang dari persentase tersebut maka akan memperpanjang usia nyamuk

Kepadatan penduduk adalah banyaknya penduduk per satuan luas. Kepadatan penduduk kasar atau crude population density (CPD) menunjukkan jumlah penduduk untuk setiap kilometer persegi luas wilayah. Luas wilayah yang dimaksud adalah luas seluruh daratan pada suatu wilayah administrasi. Kepadatan penduduk merupakan indikator dari tekanan penduduk di suatu daerah (BPS, 2016). Kepadatan penduduk termasuk salah satu faktor risiko penularan penyakit DBD. Semakin padat penduduk, nyamuk aedes aegypti semakin mudah menularkan virus dengue dari satu orang ke orang lainnya. Hal ini menyebabkan kemungkinan kejadian kasus DBD dapat meningkat. Hal ini juga terkait dengan penyediaan infrastruktur yang kurang memadai seperti penyediaan sarana air bersih, sarana pembuangan sampah sehingga terkumpul barang-barang bekas yang dapat menampung air dan menjadi tempat perkembang biakan nyamuk.

Angka bebas jentik (ABJ) merupakan ukuran yang dipakai untuk mengetahui kepadatan jentik. Cara untuk menghitungnya yaitu menghitung banyaknya rumah atau bangunan yang tidak dijumpai jentik nyamuk dibagi dengan jumlah seluruh rumah atau bangunan di lokasi tersebut. Dengan demikian, keadaan bebas jentik merupakan suatu keadaan dimana ABJ lebih atau sama dengan $95 \%$, dimana parameter yang diketahui adalah jumlah telur, jentik, dan kepompong nyamuk penular DBD (Aedes aegypti) berkurang atau tidak ada. Dengan demikian, semakin tinggi nilai ABJ suatu daerah menunjukkan semakin rendah risiko terjadinya penyakit demam berdarah dengue dan begitu juga sebaliknya, semakin rendah 
nilai $A B J$ semakin tinggi risiko penyakit DBD.

$$
A B J=\frac{\text { jumlah rumah tidak ditemukan jentik }}{\text { jumlah rumah diperiksa }} \times 100 \%
$$

ABJ merupakan salah satu ukuran metode survei jentik yang dilakukan melalui metode single larvae dan metode visual. Program DBD biasanya menggunakan metode visual (Depkes RI, 2010).

Model Geographically Weighted Regression (GWR) merupakan pemodelan pengembangan dari metode regresi. Namun, pemodelan GWR parameter persamaan pada setiap lokasi pengamatan berbeda dengan lokasi lainnya. Sehingga banyaknya vektor parameter yang diduga adalah sebanyak lokasi pengamatan yang digunakan dalam data. Dalam analisis GWR, model yang dihasilkan juga tidak daoat digunakan untuk menduga parameter selain parameter di lokasi pengamatan (Walter et al, 2005). Geographically Weighted Regression (GWR) merupakan salah satu metode statistika yang digunakan untuk memodelkan variabel respon dengan variabel prediktor yang berbasih wilayah atau area (Anselin dan Bera, 1998).

Model Geographically Weighted Regression (GWR) dapat ditulis sebagai berikut :

$Y_{i}=\beta_{0}\left(u_{i}, v_{i}\right) \sum_{k=1}^{p} \beta_{k}\left(u_{i}, v_{i}\right) X_{i k}+\varepsilon_{i}$

Dimana :

$Y_{i}$ : nilai variabel respon pada titik lokasi pengamatan ke-i

$X_{i k}$ : nilai variabel prediktor ke-k pada titik lokasi pengamatan ke-i

$\left(u_{i}, v_{i}\right)$ : koordinat titik lokasi pengamatan ke-i (longitude, latitude)

$\beta_{0}\left(u_{i}, v_{i}\right)$ : koordinat / intercept GWR

$\beta_{k}\left(u_{i}, v_{i}\right)$ : koefisien regresi ke-k pada titik lokasi pengamatan ke-i

$\varepsilon_{i}$ : error pada titik lokasi ke-i yang diasumsikan dengan ratarata nol dan varians $\sigma^{2}$

Tujuan dari penelitian ini yaitu untuk mengidentifikasi dan membuat pemodelan iricident rate BDB berkaitan dengan faktor lingkungan seperti suhu, kelembaban udara, kepadatan penduduk, dan jumlah curah hujan terhadap angka terjadi kasus demam berdarah dengue di Indonesia dengan pendekatan GWR.

\section{BAHAN DAN METODE}

Penelitian menggunakan data sekunder yang berasal dari Ditjen Pencegahan dan Pengendalian Penyakit Kemenkes RI, 2015 dan Badan Pusat Statistik (BPS) Badan Meteorologi, Klimatologi, dan Geofisika. Unit pengamatan yang digunakan pada kasus ini adalah 34 Provinsi di Indonesia.

Variabel yang digunakan meliputi variabel terikat $(\mathrm{Y})$ yaitu incident rate DBD tiap provinsi di Indonesia dan variabel bebas diantaranya adalah rata-rata suhu (X1), kelembaban (X2), kepadatan penduduk (jiwa/ $\mathrm{km}^{2}$ ) (X3) dan jumlah curah hujan (mm) $(\mathrm{X} 4)$.

Tahapan untuk menyelesaikan kasus DBD di Indonesia akibat cuaca dengan metode geographically weighted regression (GWR) sebagai berikut:

1. Menguji normalitas sisaan.

Hipotesis uji:

$\mathrm{HO}$ : residual berdistribusi normal

H1 : residual tidak berdistribusi normal Statistic Uji

$\mathrm{A}^{2}=-\mathrm{n}-\frac{1}{n} \quad \sum_{i=1}^{n}(2 i-1)(\ln (F(y i+$ $\ln \left[1-F\left(Y_{n_{+1+i}}\right)\right]$

dengan $\mathrm{F}(\mathrm{yi})$ menyatakan fungsi sebaran kumulatif dari normal baku dan yi menyatakan data yang diurutkan.

Daerah kritis:

Terima pada taraf signifikasi $\alpha$ jika $\mathrm{P}$ value $\geq \alpha$

2. Mengidentifikasi adanya multikolinearitas menggunakan variance inflation factor (VIF). Nilai VIF lebih besar dari 10 menunjukkan adanya multikolinearitas (Montgomery dan Peck, 1992)

Hipotesis uji :

$\mathrm{H}_{0}$ : Tidak ada multikolinearitas antarvariabel bebas pada model regresi.

$\mathrm{H}_{1}$ : Ada multikolinearitas antarvariabel bebas pada model regresi.

Statistik Uji : 
$\mathrm{VIF}=\frac{1}{1-R_{j}{ }^{2}}$

Tolak $\mathrm{H}_{0}$ jika nilai VIF $\geq 10$. Hal ini berarti ada multikolinearitas antarvariabel bebas pada model regresi.

3. Mengidentifikasi adanya heterogenitas spasial menggunakan uji Breusch Pagan (Anselin, 1988)

Hipotesis uji :

$\mathrm{H}_{0}: \sigma_{1}^{2}=\sigma_{2}^{2}=\ldots=\sigma_{\mathrm{n}}^{2}=\sigma^{2}$

$\mathrm{H}_{1}$ : Minimal ada satu $\sigma_{\mathrm{i}}^{2} \neq \sigma^{2}$

Statistik Uji :

$\mathrm{BP}=\frac{1}{2} f^{T} X\left(X^{T} X\right)^{-1} X^{T} f$

Dengan :

$f_{i}=\frac{e_{i}^{2}}{\sigma^{2}}-1$

$\sigma^{2}=\sum_{i=1}^{n} e_{i}^{2}$

$e_{i}^{2}=\sum_{i=1}^{n}\left(Y_{i}-Y_{i}\right)^{2}$

Tolak $\mathrm{H}_{0}$ jika nilai $\mathrm{BP} \geq X_{k}{ }^{2}$ dengan taraf signifikan $\alpha$ atau $p$-value $\geq \alpha$. Hal ini berarti adanya heterogenitas spasial pada data.

4. Setelah mendapatkan variabel bebas yang signifikan selanjutnya membentuk model GWR lokal. Membentuk model GWR local berdasarkan matriks pembobot

5. Menguji kesesuaian model GWR dengan uji $\mathrm{F}$.

Hipotesis uji:

HO : $\beta \mathrm{k}$ ( hi,ui, vi) $=\beta \mathrm{k}$

$\mathrm{H} 1$ : minimal ada satu $\beta \mathrm{k}$ ( hi,ui, vi) $\neq \beta \mathrm{k}$

Statistic uji :

Fhitung $=\frac{\frac{\mathrm{RSS}(\mathrm{H} 0)-\mathrm{RSS}(\mathrm{H} 1)}{\tau 1}}{\frac{\mathrm{RSS}(\mathrm{h} 1)}{\delta 1}}$

$\operatorname{RSS}\left(\mathrm{H}_{0}\right)$ menyatakan jumlah kuadrat sisaan model regresi linear klasik dan $\operatorname{RSS}\left(\mathrm{H}_{1}\right)$ menyatakan jumlah kuadrat sisaan model GWR. $F_{\text {tabel }}$ dapat dicari dengan distribusi $F$ menggunakan derajat bebas

$d f_{1}=\frac{\tau_{1}{ }^{2}}{\tau_{2}}$ dan $\quad d f_{2}=\frac{\delta_{1}{ }^{2}}{\delta_{2}}$ pada taraf signifikans $\alpha, \quad \tau_{1}=\operatorname{tr}[(I-H)-$ $\left.(I-L)^{T}(I-L)\right]^{i}$
Daerah Kritis :

Tolak $\mathrm{H}_{0}$ jika $F_{\text {hitung }} \geq F_{\text {tabel }}$. Hal ini berarti ada perbedaan signifikans antara model regresi linear dengan GWR.

6. Menguji uji signifikans parameter model GWR dengan $t$.

Hipotesis Uji :

$\mathrm{H}_{0}: \beta_{k\left(h_{i}, u_{j}, v_{j}\right)}=0$

$\mathrm{H}_{1}$ : Minimal ada satu $\beta_{k\left(h_{i}, u_{j,}, v_{j}\right)} \neq 0$

Statistik Uji :

$$
t_{\text {hitung }}=\frac{\beta_{k\left(h_{i}, u_{j}, v_{j}\right)}}{S E \beta_{k\left(h_{i}, u_{j}, v_{j}\right)}}
$$

Dengan $\beta_{k\left(h_{i}, u_{j,}, v_{j}\right)}$ menyatakan koefisien regresi pada koordinat letak geografis (bujur, lintang, ketinggian) ke-i dan $S E \beta_{k\left(h_{i}, u_{j}, v_{j}\right)}$ menyatakan standar error penduga parameter $\beta_{k}$.

$t_{\text {tabel }}$ dapat dicari dengan distribusi $\mathrm{t}$ menggunakan derajat bebas $\quad d f=\frac{\delta_{1}{ }^{2}}{\delta_{2}}$ pada taraf signifikans $\alpha$.

Daerah Kritis :

Tolak $\mathrm{H}_{0}$ jika $t_{\text {hitung }} \geq t_{\text {tabel }}$ taraf signifikan. Hal ini berarti ada pengaruh signifikan antara variabel bebas dengan variabel terikat.

\section{HASIL DAN PEMBAHASAN}

\section{Statistika deskriptif}

Variabel yang digunakan dalam penelitian ini terdiri dari satu variabel respon dan empat variabel prediktor. Variabel respon pada penelitian ini adalah incident rate DBD tiap provinsi di Indonesia dan variabel prediktornya adalah rata- rata suhu (X1), kelembapan udara (X2), kepadatan penduduk (jiwa/ $/ \mathrm{km}^{2}$ ) (X3) dan jumlah curah hujan (mm) (X4), Berikut ini merupakan statistika deskriptif untuk variabel respon dan semua variabel prediktor. Statistika deskriptif dapat dilihat pada Tabel 1 dan pemetaan Incident Rate DBD Di Indonesia Tahun 2015 dapat dilihat pada Gambar 1. 
Tabel 1. Statistika deskriptif

\begin{tabular}{|c|c|c|c|}
\hline Variable & Mean & Minimum & Maximum \\
\hline $\mathrm{Y}$ & 41.81 & $\begin{array}{c}0.91 \\
\text { (Kalimantan Barat }\end{array}$ & $\begin{array}{c}3.800 \\
\text { (Nusa Tenggara Barat) }\end{array}$ \\
\hline $\mathrm{X} 1$ & 5.22 & $\begin{array}{c}5.11 \\
\text { (Nusa Tenggara Timur) }\end{array}$ & $\begin{array}{c}5.34 \\
\text { (DKI Jakarta) }\end{array}$ \\
\hline $\mathrm{X} 2$ & 8.927 & $\begin{array}{c}8.370 \\
\text { (DKI Jakarta) }\end{array}$ & $\begin{array}{c}9.320 \\
\text { (Sumatera Utara) }\end{array}$ \\
\hline $\mathrm{X} 3$ & 2.107 & $\begin{array}{c}1.200 \\
\text { (Kalimantan Selatan) }\end{array}$ & $\begin{array}{c}3.090 \\
\text { (Bali) }\end{array}$ \\
\hline $\mathrm{X} 4$ & 41.81 & $\begin{array}{c}\text { 21.47 } \\
\text { (Sulawesi Tengah) }\end{array}$ & (Sumatera Barat) \\
\hline
\end{tabular}

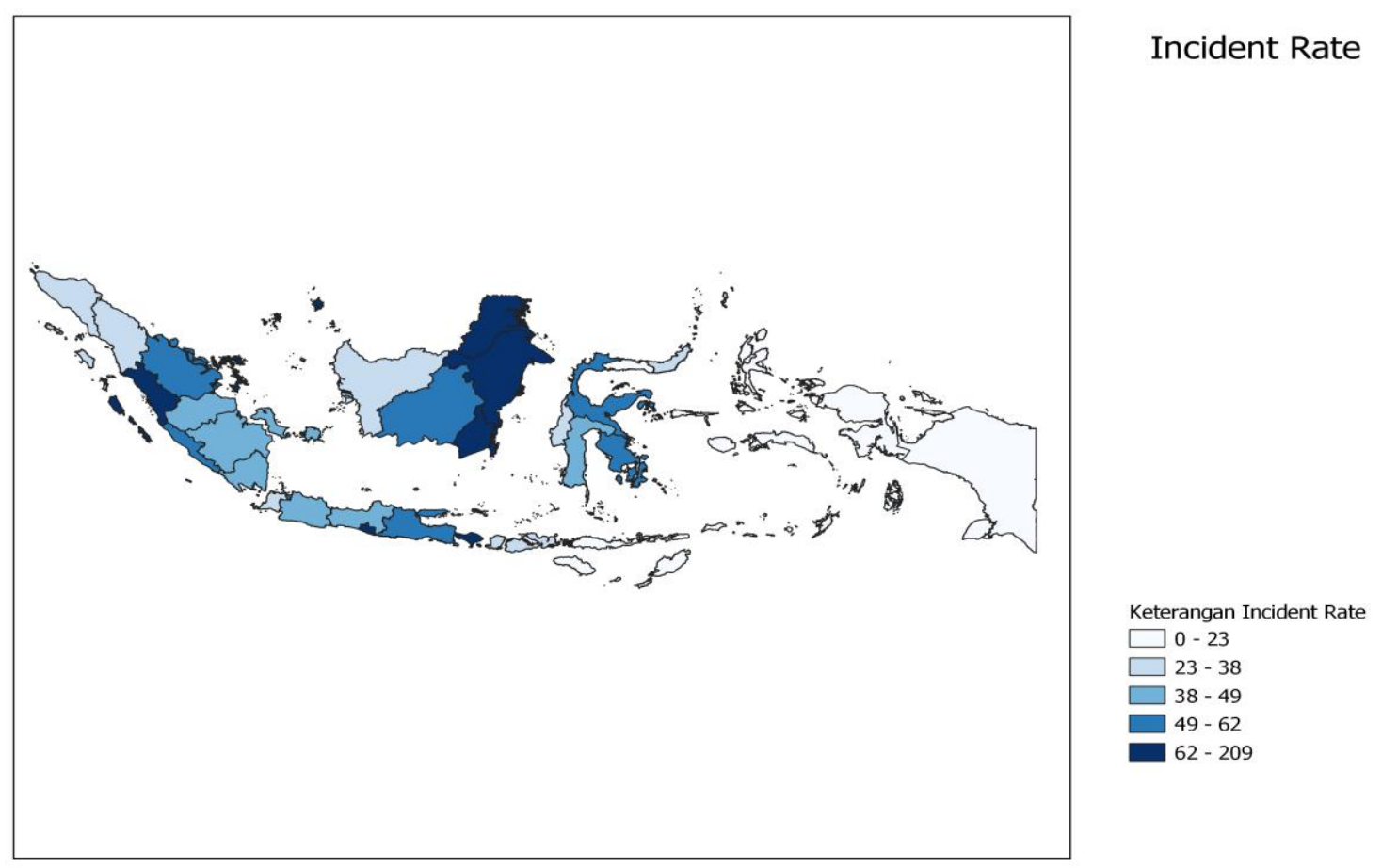

Gambar 1. Peta Incident rate DBD di Indonesia tahun 2015

Pada peta ditunjukkan kelompok provinsi dengan incident rate DBD yang tinggi dengan warna biru tua dan yang terendah dengan warna mendekati putih. Provinsi dengan Incident Rate tertinggi diantarnya adalah Sumatera Barat, Kepulauan Riau, D.I Yogyakarta, Bali, Kalimantan Tengah, Kalimantan Selatan, Kalimantan Timur dan Kalimantan Utara, sedangkan Incident Rate DBD terendah yaitu provinsi Nusa Tenggara Timur, Maluku, Maluku Utara, Papua Barat dan Papua.

\section{Uji Normalitas.}

Model regresi yang baik adalah distribusi data normal atau mendekati normal. Hipotesis yang digunakan dalam pengujian asumsi respon berdistribusi Normal ini adalah sebagai berikut. $\mathrm{H}_{0}$ : Residual berdistribusi normal $\mathrm{H}_{1}$ : Residual tidak berdistribusi normal Pengujian asumsi residual berdistribusi Normal menggunakan uji Kolmogorov Smirnov atau Shapiro wilk didapat $p$-value $=1.193 \mathrm{e}-05<\alpha=0.05$ maka $\mathrm{H}_{0}$ ditolak artinya residual tidak berdistribusi normal. Karena data tidak berdistribusi normal maka langkah yang kita lakukan 
selanjutnya adalah mentransformasikan data atau membuang outlier pada data sehingga data yang sudah ditransformasikan didapat nilai $p$-value $=0.2528>\alpha=0.05$ maka $\mathrm{H}_{0}$ diterima artinya residual sudah berdistribusi normal. Dilihat dari histogram sebaran data membentuk lonceng menandakan residual berdistribusi normal.

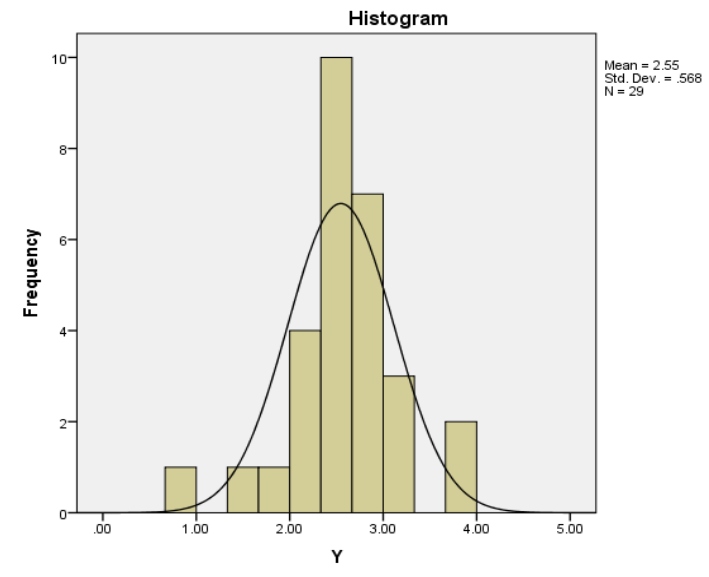

Gambar 2. Histogram incident rate DBD

\section{Multokolinieritas}

Multikolinearitas merupakan kondisi dimana variabel-variabel bebas dalam data memiliki korelasi yang kuat sehingga penaksirnya akan bias dan tidak stabil. Untuk melihat data mengadung multikol dilakukan pengujian asumsi dengan melihat nilai VIF (variance inflation factors). Data yang terdapat multikolinearitas nilai VIF nya besar dari 10 yang menunjukkan bahwa terdapat korelasi yang tinggi antar variabel prediktor. Dari output terlihat bahwa untuk keempat variable nilai VIF nya kecil dari 10 , hal ini menunjukkan bahwa tidak terdapat multikolinearitas pada data yang digunakan.

\begin{tabular}{cc}
\multicolumn{2}{c}{ Tabel 2. Nilai VIF } \\
\hline Variable & VIF \\
\hline $\mathrm{X} 1$ & 2.087439 \\
$\mathrm{X} 2$ & 2.219958 \\
$\mathrm{X} 3$ & 1.183111 \\
$\mathrm{X} 4$ & 1.128916 \\
\hline
\end{tabular}

\section{Model regresi Ordinary Least Square (OLS)}

Dengan software $\mathrm{R}$ didapatkan permodelan dengan metode OLS sebagai berikut :

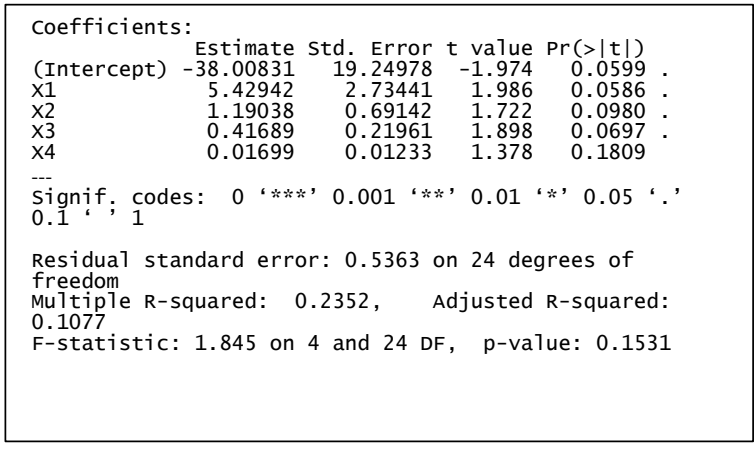

Berdasarkan hasil output pada $R$ diatas maka didapat model regresinya adalah :

$$
\begin{aligned}
y=-38.00831 & +5.42942 \times 1 \\
& +1.19038 \times 2 \\
& +0.41689 \times 3 \\
& +0.01699 \times 4
\end{aligned}
$$

\section{Pengujian Signifikansi Parameter}

Untuk mengetahui variable mana saja pada data yang berpengaruh signifikanas maka maka dilakukan pengujian signifikansi parameter secara parsial. Dengan hipotesis sebagai berikut

$H 0: \beta k=0$

$H 1: \beta k \neq 0 ; k=1,2, \ldots, 7$

Tabel 3. Signifikansi parameter

\begin{tabular}{lc}
\hline \multicolumn{1}{c}{ Variabel } & $\boldsymbol{P}$-value \\
\hline $\begin{array}{l}\text { Rata- rata suhu } \\
\text { Kelembapan } \\
\text { udara }\end{array}$ & 0.0586 \\
$\begin{array}{l}\text { Kepadatan } \\
\text { penduduk }\end{array}$ & 0.0980 \\
$\begin{array}{l}\text { Jumlah curah } \\
\text { hujan }\end{array}$ & 0.0697 \\
\hline
\end{tabular}

Dengan menggunakan alpha 5\% maka dapat disimpulkan bahwa variable berpengruh signifikans terhadap iricident rate karena variabel memiliki nilai $P$-value $>0,05$.

\section{Pengujian Heterogenitas Spasial}

Hipotesis nya adalah sebagai berikut $\mathrm{H}_{0}: \sigma_{1}{ }^{2}=\sigma_{2}{ }^{2}=\ldots=\sigma_{\mathrm{n}}{ }^{2}=\sigma^{2}$ (tidak terdapat heterogenitas spasial)

$\mathrm{H}_{1}$ : Minimal ada satu $\sigma_{\mathrm{i}}^{2} \neq \sigma^{2}$ (ada heterogenitas spasial)

Statistik Uji : 


$$
\mathrm{BP}=\frac{1}{2} f^{T} X\left(X^{T} X\right)^{-1} X^{T} f
$$

Dengan pengujian menggunakan Breusch Paganmaka didapatkan $\mathrm{P}$ value 0.9088 maka H0 ditolak artinya ada heterogenitas spasial atau ada keberagaman dalam hubungan secara kewilayahan.

\section{Geographically Weighted Regression (GWR )}

Pemodelan

Geographically

Weighted Regression (GWR) dilakukan dengan memasukan pembobot spasial dengan metode weighted least square. Matrik pembobot yang digunakan merupakan matrik yang elemenya merupakan fungsi kernel yang terdiri dari jarak antar lokasi dan bandwidth. Fungsi kernel yang digunakan dalam pemodelan GWR dipilih dengan melihat nilai AIC terkecil dari hasil pemodelannya.

Tabel 4. Nilai AIC

\begin{tabular}{lcc}
\hline \multicolumn{1}{c}{ Model } & AIC & $\boldsymbol{R}$-sq \\
\hline Regresi Linier & & $10.77 \%$ \\
GWR & & \\
$\quad$ Gaussian & 35.19843 & $56.3 \%$ \\
Bisquare & 44.16223 & $28.7 \%$ \\
Adaptive Gaussian & 35.93071 & $55.7 \%$ \\
Adaptive Bisquare & 43.51984 & $30.7 \%$ \\
\hline
\end{tabular}

Nilai AIC terkecil diperoleh dari pemodelan dengan fungsi kernel gaussian. fungsi kernel adaptive memiliki bandwidth yang berbeda-beda di setiap lokasi pengamatan. Setelah menentukan fungsi kernel yang digunakan, selanjutnya menentukan bandwidth untuk setiap lokasi yang diamati. Setelah diperoleh nilai bandwidth maka langkah yang perlu dilakukan berikutnya yaitu mencari matriks pembobot.

Matrik pembobot yang diperoleh untuk tiap-tiap lokasi kemudian digunakan untuk membentuk model sehingga tiap-tiap lokasi memiliki model yang berbeda-beda. Rangkuman hasil estimasi parameter model GWR dapat dilihat pada Table 5 sebagai berikut
Tabel 5. Nilai $\beta$ (ui,vi)

\begin{tabular}{lrrrr}
\hline & \multicolumn{3}{c}{ Nilai $\beta($ ui,vi) } & \multirow{2}{*}{ Global } \\
\cline { 2 - 4 } & \multicolumn{1}{c}{ Min } & \multicolumn{1}{c}{ Median } & Max & \\
\hline \multirow{2}{*}{ x,Inter } & -86.28195 & -36.9388285 & 14.4504559 & -38.0083 \\
& & 5.1965018 & 12.7116543 & 5.4294 \\
& - & & & \\
x2 & 0.358175 & & & \\
& 9 & 1.2869415 & 3.0544952 & 1.1904 \\
x3 & 0.005843 & & & \\
& 3 & 0.3389536 & 0.8510456 & 0.4169 \\
x4 & 0.004635 & & & \\
R-sq & 9 & 0.0146914 & 0.0194050 & 0.0170 \\
SSE & $55.7 \%$ & & & $10.77 \%$ \\
\hline
\end{tabular}

Nilai R-sq pemodelan GWR diperoleh sebesar 55,7\%, hal ini berarti sebanyak 55,7 variabel respon dapat dijelaskan oleh variabel prediktor. Jika dibandingkan dengan R-sq pemodelan dengan regresi linier berganda diperoleh sebesar $10.77 \%$, maka untuk sementara pemodelan dengan GWR dikatakan lebih baik.

Untuk melihat apakah pemodelan dengan menggunakan GWR menghasilkan model yang lebih baik dilakukan pengujian kesesuaian model dengan hipotesis sebagai berikut.

$$
\begin{aligned}
& H_{0}: \beta_{k}\left(u_{i}, v_{i}\right)=\beta_{k} \\
& H_{0}: \beta_{k}\left(u_{i}, v_{i}\right) \neq \beta_{k}
\end{aligned}
$$

Analysis of Variance Table

Df Sum Sq Mean Sq $P$ value

OLS Residuals $\quad 5.00006 .9028$

GWR Improvement 1.35930 .6546

0.48156

GWR Residuals $22.6407 \quad 6.2482$

$0.27597 \quad 1.745$

Berdasarkan hasil uji $F$ pada $R$ diperoleh Fhitung model GWR yaitu 1.745. $\mathrm{H} 0$ ditolak artinya terdapat perbedaan yang signifikan antara model GWR dan model regresi linier.

\section{Pengujian Signifikansi Parameter}

Pengujian signifikansi model GWR secara parsial dilakukan untuk mengetahui parameter-parameter yang signifikan di setiap wilayah. Hipotesis yang digunakan dalam pengujian signifikansi model GWR secara parsial adalah sebagai berikut. 
$H_{0}: \beta_{k}\left(u_{i}, v_{i}\right)=0$

$H_{0}: \beta_{k}\left(u_{i}, v_{i}\right) \neq 0$

Tabel 6. Hasil estimasi parameter GWR

\begin{tabular}{|c|c|}
\hline Variabel signifikan & Provinsi \\
\hline $\mathrm{X} 1$ & $\begin{array}{l}\text { Kepulauan Riau, Jawa } \\
\text { Timur, Banten, Nusa } \\
\text { Tenggara Barat, Nusa } \\
\text { Tenggara } \\
\text { Kalimantan Timur, } \\
\text { Kalimantan } \\
\text { Kalimantan Tarat, } \\
\text { Kalimantan Tengah, } \\
\text { Kalimantan Selatan, } \\
\text { Sulawesi Utara, Sulawesi } \\
\text { Tengah, Utara, } \\
\text { Selatan, Sulawesi } \\
\text { Tenggara, Gorontalo, } \\
\begin{array}{l}\text { Sulawesi Barat, Maluku, } \\
\text { Maluku Utara }\end{array}\end{array}$ \\
\hline $\mathrm{X} 2$ & 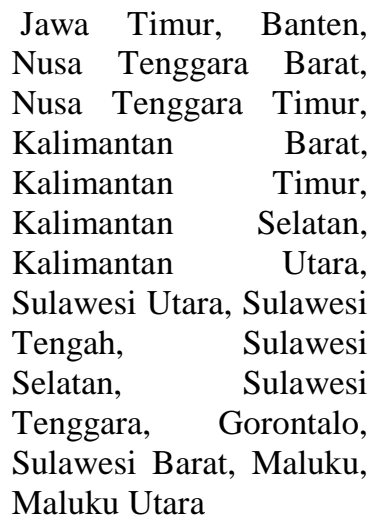 \\
\hline
\end{tabular}

X3 Kepulauan Riau, Jawa Timur, Banten, Nusa Tenggara Barat, Nusa Tenggara Timur, Kalimantan Barat, Kalimantan Timur, Kalimantan Tengah, Kalimantan Selatan, Kalimantan Utara, Sulawesi Utara, Sulawesi Tengah, Sulawesi Selatan, Sulawesi Tenggara, Gorontalo, Sulawesi Barat, Maluku, Maluku Utara

$\mathrm{X} 4$

Berdasarkan hasil pengujian signifikansi parameter dengan diperoleh parameter yang signifikan berbeda-beda untuk tiap Provinsi dengan menggunakan $\alpha$ $=10 \%$, maka didapatkan $t\left(\frac{\alpha}{2}, n-k-1\right)=$ OPEN ACCESS
1,714. Hasil estimasi parameter GWR yang signifikan setiap lokasi pengamatan dapat dilihat pada Tabel 6 .

Berdasarkan hasil pengelompokan parameter yang signifikans, maka dapat dilihat untuk setiap provinsi parameter yang signifikans berbeda- beda. Sehingga dapat kita ambil contoh persamaan GWR ntuk provinsi kepulauan riau yaitu :

$$
y=-1.4829+4.6798 \times 1
$$

\section{KESIMPULAN}

Pemodelan incident rate DBD di indonesia yang berkaitan dengan faktor lingkungan menggunakan metode Geographycal Wighted Regression (GWR). Bila ditinjau dari hasil penelitian ini dimana model GWR memiliki R $^{2}$ sebesar Nilai R-sq pemodelan GWR diperoleh sebesar 55,7\%, hal ini berarti sebanyak 55,7 variabel respon dapat dijelaskan oleh variabel prediktor. Jika dibandingkan dengan R-sq pemodelan dengan regresi linier berganda diperoleh sebesar $10.77 \%$. Untuk setiap provinsi parameter yang signifikan berbeda-beda di tiap daerah.

\section{DAFTAR PUSTAKA}

Anselin, L. (1988). "Spatial Econometrics: Methods and Models". Kluwer Academic Publishers, Dordrecht.

Anselin, L. Dan Bera, A. (1998). Spasial Dependence In Linier Regression Models With An Introduction To Spatial Econometries. Dalam Ullah, A. \& Gilles, D Handbook of Applited Economies Statistic. Selected reading, pp. 237-289. Marcel Dekker: New York.

Badan Pusat Statistik. (2016). Kepadatan Penduduk. Tersedia di: https://sirusa.bps.go.id/sirusa/index.ph p/indikator/85.

Depkes RI. (2010). Buku 3: Pemberantasan Nyamuk Penular Demam berdarah dengue. Depkes RI: Jakarta.

Koesnayani, A. S., \& Hidayat, A. K. (2018). Hubungan antara pola curah hujan dengan kejadian DBD di Kota Tasikmalaya tahun 2006-2015 (kajian 
jumlah curah hujan dan hari hujan). Jurnal Siliwangi. 4(1): 14-19.

Lahdji A., Putra, B.B., (2017). Hubungan Curah Hujan, Suhu, Kelembaban dengan Kasus Demam Berdarah Dengue di Kota Semarang. Syifa Medika: Jurnal Kedokteran dan Kesehatan. 8 (1): 46-53.

Montgomery, D.C., Peck, E.A., \& Vining, G.G. (1992). Introduction to Linear Regression Analysis. Toronto: John Wiley \& Sons.
Regariana, M. (2004). Atmosfer (Cuaca dan Iklim). Solo: Tiga Serangkai. Tersedia di: https:// andimanwno.fi les.wordpress.com/2010/08/ atmosfercuaca-dan-iklim.pdf

Walter J, Carsten R and Jeremy W Lichstein. (2005). Local and Global Approaches to Spatial Data Analysis in Ecology. Global Ecology and Biogeography. 14: 97-98. 